\title{
Different Approaches to Manage Type-2 Diabetes: Special Emphasis on Dietary Fibre
}

\author{
Ovais Shafiq Qadri*, Kaiser Younis and Soban Ahmad Faridi \\ Department of Bioengineering, Integral University, Lucknow, India
}

Submission: November 06, 2017; Published: December 18, 2017

*Corresponding author: Ovais Shafiq Qadri, Department of Bioengineering, Integral University Lucknow, India, Tel: +91-9419041070; Email: osqonline@gmail.com

\begin{abstract}
In recent years, several deaths have been reported due to diabetes worldwide and India is no exception. A proper care of diet and constant medication is the only way to counter this disease presently. It is very difficult for a diabetic patient to keep a tab on his cumbersome diet plan and this has led to an enormous responsibility on scientists, particularly those related to food and nutrition, to look for solutions to this problem. High sugar or starch-containing foods are the target foods which diabetic patients cannot consume in a normal quantity. Actually, these foods have high glycemic index and increase the blood sugar level abruptly after their consumption and unfortunately, such foods are mostly staple like rice and wheat products and are an integral part of any diet throughout the world. In countries like India the consumption of rice and/or wheat is directly related to the satiety value of people and if someone skips rice or bread from his meals, he remains hungry psychologically. So, it is very difficult to have a control on the consumption of such foods. Incorporation of dietary fibre in such foods is one of the best solutions for this problem and market is providing consumers with a variety of such products. Dietary fibre has an ability to absorb the glucose in the small intestines and ensure a controlled release of this glucose into the bloodstream, thus, preventing the abrupt rise in blood glucose level. Both the demand and the variety of dietary fibre fortified foods are on the increase which is undoubtedly a positive sign. This mini-review presents the approaches presently being administered and researched to prevent and control diabetes including the role of different drugs and diet management.
\end{abstract}

Keywords: Dietary fibre; Glycemic Index; Diabetic; Blood Glucose; Insulin

\section{Introduction}

Type 2 diabetes occurs due to deficiency of insulin (malfunctioning of pancreatic beta cells) or by insulin resistance which affects the glucose transportation from blood to cells. In 1985, the diabetic population of the world was 30 million which has increased to 415 million in 2015 and is expected to cross 642 million in the year 2040 [1] and this alarming prevalence may be attributed to obesity, lifestyle, stress, and bad diet [2]. Type 2 diabetes can be prevented by controlling the obesity, practicing exercise and reducing glucose intake $[3,4]$. Foods with a high glycemic index like sugar cannot be consumed by diabetic patients in a normal quantity. Upon consumption, such foods can abruptly increase the blood sugar level. Staple foods like rice and wheat including their products which are an integral part of any diet throughout the world are also grouped under such category. Asking people to avoid such food that is a part of the culture and is being consumed from generations is not-at-all an easy task. One of the possible solutions to this problem may be the modification of the nutritional composition of traditional foods with least compromise in sensory quality attributes, for instance, incorporation of dietary fibre. Dietary fibres have been reported to possess many health benefits. Dietary fibres are the non-digestible part of edible foods which can be soluble or insoluble. Fruits are the good source of soluble fibre whereas cereals are a good source of insoluble fibre. Among the different health benefits, the postprandial control of blood glucose levels after the consumption of high glycemic index foods has been shown by different fibre sources $[5,6,7]$.

\section{Medicines for type 2 diabetes}

Type 2 diabetes is a threat to our society and precise medication and highly personalized approach is the hope to achieve better outcomes. Many useful medications are available in the market that has been used to treat type 2 diabetes. Some of them are discussed as.

\section{Metformin}

The trade name for metformin is Glucophage and is used as a first line medicine for the treatment of type 2 diabetes. Liver glucose production is suppressed (hepatic gluconeogenesis) by the consumption of metformin hence, there is a decrease in the blood glucose level.

\section{Glucagon-Like Peptide 1 Receptor Agonists}

This drug is used for the treatment of type 2 diabetes. It maintains the normal blood glucose levels in the body by increasing the insulin secretion from the pancreas in addition to slowing the process of glucagon secretion. 


\section{Thiazolidinediones}

These are the compounds which regulate lipid and glucose metabolism in liver, muscles and adipose by activating the peroxisome proliferator-activated receptor-gamma due to which insulin sensitivity increases and blood glucose level decreases.

Sulfonylure as bind to ATP sensitive K+ and close channels in the beta cell membrane and cause depolarization which increases the intracellular calcium. This, in turn, leads to increase in the fusion of insulin vesicles with the cell membrane and thus increases the secretion of insulin.

Acarbose is an inhibitor of alpha-glucosidase which is used in the patients with type 2 diabetes. It delays the carbohydrate digestion and absorption in intestines hence decreases the postprandial hyperglycaemia.

Dipeptidyl peptidase 4 inhibitor prevents the degradation of in cretins and stimulates the insulin release in addition to inhibition of glucagon release thereby lowering the body blood glucose level.

Sodium-Glucose co transporter 2 (SGLT2 inhibitors) is a protein found in apple bark with powerful anti-diabetic effects. It increases the urinary excretion of glucose by inhibiting the SGLT2 which otherwise reabsorbs the glucose from urine thus lowering the blood glucose level.

Insulin is produced by the DNA recombined technique and is administered as subcutaneous injections by using syringes, pumps, inhalers or insulin pens [8].

The estimated cost of the drugs recommended to diabetic patients has estimated at more than $\$ 100$ billion per year in the United States alone. Drugs in use for type 2 diabetes are 2 to 3 times costlier compared to drugs for other diseases. People in developed countries are able to procure such drugs but for the other countries where most of the people are economically weak, alternatives to these expensive drugs are the need of the hour [9]. Since, this disease is directly related to what we eat, so nutritionally modified foods for diabetic people can be one such alternative.

\section{Dietary Fibre and Diabetics}

The consumption of high carbohydrate-containing foods increases the blood glucose level of diabetic patients abnormally and therefore, such patients need to take necessary precautions after consumption of high carbohydrate meals. Diet management has reportedly shown promising results in dealing with diabetes. There are several dietary approaches to control the blood glucose. Type and the amount of the carbohydrate affect the blood glucose level [10]. One can manage the carbohydrate intake by keeping the amount of carbohydrate intake constant and incorporating appropriately fixed dose of insulin or another hypoglycemic drug. On the other hand, a patient can follow the carbohydrate counting method. In this approach, a patient's diet does not remain constant so the patient has to adjust insulin intake accordingly [10].

Some functional foods have been studied for a long time now for their possible role in prevention and treatment of diabetes and at the same time fulfilling the criteria of being a complete food. Among such foods, those high in dietary fibre content have shown a versatile effect on blood glucose control. Foods can either be naturally rich in dietary fibre or incorporation of dietary fibre in foods is also possible and both have been proven to be useful for the diabetic patients $[11,12,13,14]$. Lot of work has been done on the incorporation of dietary fibre, a few examples of which have been summarized in Table 1.

Table 1: Dietary fibre incorporated foods useful for diabetic patients.

\begin{tabular}{|c|c|c|c|}
\hline S. No. & Food Product & Type of fibre & References \\
\hline 1 & Bread & Dietary fibre and L-carnitine & {$[15]$} \\
\hline 2 & Flat bread & Banana peels & {$[16]$} \\
\hline 3 & Jam & Tomato pomace & {$[18]$} \\
\hline 4 & Noodle, steamed bread or bread & Okara (by-product of tofu) & {$[19]$} \\
\hline 5 & Cookies & Mosambi peel & {$[20]$} \\
\hline 6 & Papaya Jam & Mosambi peel & {$[21]$} \\
\hline 7 & Sausages & Apple pomace & {$[22]$} \\
\hline 8 & Sausages and Patties & Prape pomace and grape seed & {$[23]$} \\
\hline 9 & Cookies & Gilaburu fruit pomace & {$[24]$} \\
\hline 10 & Cake & Barley Flour & {$[25]$} \\
\hline 12 & Wheat chips & Mango peel powder & {$[26]$} \\
\hline
\end{tabular}


In addition to dietary fibre incorporated foods, consumption of whole foods is also believed to be beneficial for diabetic patients. The whole foods are minimally processed or refined in which most of the edible part is retained and the addition of additives and other artificial substances is avoided. The whole foods include cereals, fruits, vegetables, pulses and others. Several epidemiologic studies have concluded that the diets rich in whole grains may safeguard against type 2 diabetes [28,29]. The positive effects of whole grains on diabetics have been attributed to the presence of biologically active constituents, including dietary fibre [30]. Fruit is an important component of our daily diet. In addition to the bioactive compounds, fruits are a good source of soluble fibre. Some of the fruits high in dietary fibre content are litchi, durian, jackfruit, mangosteen, pomegranate, guava and avocado [31,32,33]. Whole pulses are also a good source of low glycemic index carbohydrates and contain 4 to $7 \%$ of dietary fibre [34]. Vegetables are low in sugars and contain a good amount of fibre which can help in preventing the abrupt blood glucose level when consumed with meals. From the above discussions, it may be concluded that there is a positive link between dietary fibre intake and prevention and control of diabetes, the mechanism of which is simply summarized in Figure 1.

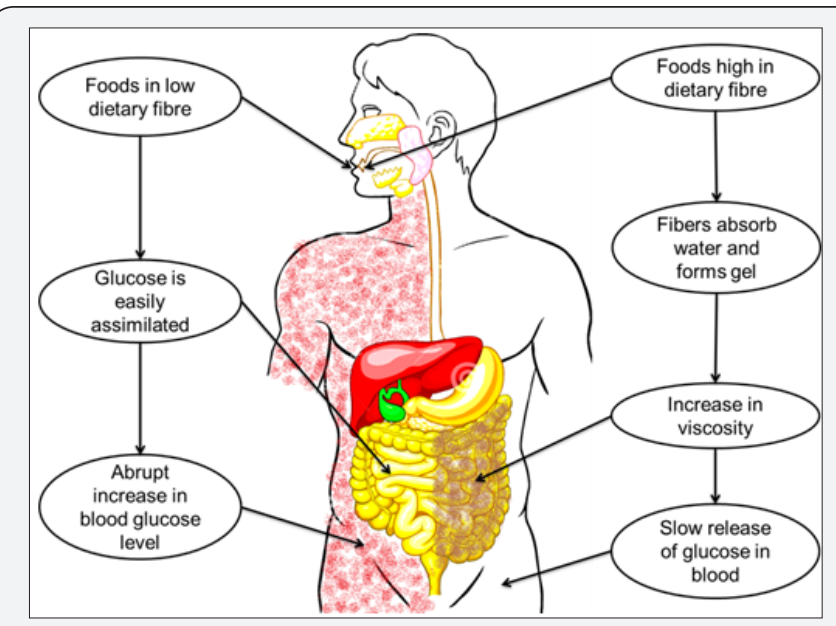

Figure 1: MEChanism of PREVENTING ABRUPT GLUCOSE LEVEL WITH HIGH FIBRE DIETS.

\section{Conclusion}

Prevention of any disease is the best possible solution to it but that may not be practical always. Food has got a direct role in the onset as well as management of type-2-diabetes. A proper diet as per the physical requirements of a person can minimize the risk of getting diabetic. Any person who is suffering from diabetes can better manage the disease by following a proper diet plan. The role of dietary fibre in blood glucose management is well established and the diabetic people are being benefitted by foods which are high in dietary fibre naturally or in which dietary fibre has been incorporated. Although a wide range of high fibre foods are already available and the new ones are hitting the market regularly, the need is to bring such changes in the regular meals in addition to making them more economical.

\section{References}

1. International Diabetes Federation (2015) IDF Diabetes Atlas, $\left(7^{\text {th }}\right.$ edn), Brussels, Belgium.

2. NCD Risk Factor Collaboration (NCD-RisC) (2016). Worldwide trends in diabetes since 1980: a pooled analysis of 751 population-based studies with 4.4 million participants. Lancet 387: 1513-1530.

3. Orozco LJ, Buchleitner AM, Gimenez-Perez G, Roque I Figuls M, et al. (2008) Exercise or exercise and diet for preventing type 2 diabetes mellitus. Cochrane Database Syst Rev 3: CD003054.

4. Merlotti C, Morabito A, Pontiroli AE (2014) Prevention of type 2 diabetes a systematic review and meta-analysis of different intervention strategies. Diabetes ObesMetab 16(8): 719-727.

5. Yu K, Ke M, Li W, Zhang S, Fang X (2014) The impact of soluble dietary fibre on gastric emptying, postprandial blood glucose and insulin in patients with type 2 diabetes. Asia Pac J Clin Nutr 23(2): 210-218.

6. Hlebowicz J, Darwiche G, Björgell O, Almér L (2008) Effect of muesli with $4 \mathrm{~g}$ oat beta-glucan on postprandial blood glucose, gastric emptying and satiety in healthy subjects: a randomized crossover trial. J Am CollNutr 27(4): 470-475.

7. Health Canada (2016) Summary of Health Canada's assessment of a health claim about a polysaccharide complex (glucomannan, xanthan gum and sodium alginate) and a reduction of the post-prandial blood glucose response. Bureau of Nutritonal Sciences, Health Canada, Ottawa, Canada.

8. Chi C, Snaith J, Gunton JE (2017) Diabetes Medications and Cardiovascular Outcomes in Type 2 Diabetes. Heart Lung Circ 26(11): $1133-1141$.

9. Reddy SS (2016) Evolving to Personalized Medicine for Type 2 Diabetes. Endocrinol Metab Clin North Am 45(4): 1011-1020.

10. Sheard NF, Clark NG, Brand-Miller JC, Franz MJ, Pi-Sunyer FX, et al (2004) Dietary carbohydrate (amount and type) in the prevention and management of diabetes: a statement of American Diabetes Association. Diabetes Care 27(9): 2226-2271.

11. Giacco R, Clemente G, Riccardi G (2002) Dietary fibre in treatment of diabetes: myth or reality? Dig Liver Dis 34(Suppl 2): S140-144.

12. Goff HD, Repin N, Fabek H, Khoury DEI, Gidley MJ (2017) Dietary fibre for glycaemia control: Towards a mechanistic understanding.

13. Anderson JW, Baird P, Davis RH, Ferreri S, Knudtson M, et al. (2009) Health benefits of dietary fibre. Nutr Rev 67(4): 188-205.

14. Brownlee I (2014) The impact of dietary fibre intake on the physiology and health of the stomach and upper gastrointestinal tract. Bioact Carbohydrates Diet Fibre 4(2): 155-169.

15. Banuls C, Rovira-Llopis S, Monzo N, Sola E, Viadel B, et al. (2015) The consumption of a bread enriched with dietary fibre and L-carnitine improves glucose homoeostasis and insulin sensitivity in patients with metabolic syndrome. J Cereal Sci 64: 159-167.

16. Eshak SN (2016) Sensory evaluation and nutritional value of baladyflat bread supplemented with banana peels as a natural source of dietary fibre. Ann AgricSci 61(2): 229-235.

17. Belovic M, Torbica A, Pajic-Lijakovic I, Mastilovic J (2017) Development of low calorie jams with increased content of natural dietary fibre made from tomato pomace. Food Chem 237: 1226-1233.

18. Lu F, Liu Y, Li B (2013) Okara dietary fibre and hypoglycemic effect of okara foods. Bioact Carbohydrates Diet Fibre 2: 126-132. 
19. Younis K, Islam R, Jahan K, Kandu M, Ray A (2015) Investigating the Effect of Mosambi (Citrus limetta) Peel Powder on Physicochemical and Sensory Properties of cookies. Qual Assur Saf Crop Foods 8(3): 393-398.

20. Younis K, Islam R, Jahan K, Yousuf B, Ray A (2015) Effect of addition of mosambi (Citrus limetta) peel powder on textural and sensory properties of papaya jam. Cogent Food Agric 1: 1023675.

21. Younis K, Ahmad S (2015) Waste utilization of apple pomace as a source of functional ingredient in buffalo meat sausage. Cogent Food Agric 1: 1119397

22. Younis K, Ahmad S (2017) Investigating the Functional Properties of Pineapple Pomace Powder and Its Incorporation in Buffalo Meat Products. Plant based natural products: Derivates and applications. Willey-Scrivener. Chapter 9, pp 175-192.

23. Acun S, Gül H (2014) Effects of grape pomace and grape seed flours on cookie quality. Qua Assur Saf Crop Foods 6(1): 81-88.

24. Şeker IT, Ertop MH, Hayta M (2016) Physicochemical and bioactive properties of cakes incorporated with gilaburu fruit (Viburnum opulus) pomace. QualAssur Saf Crop Foods 8(2): 261-266.

25. Yuksel F, Karaman S, Kayacier A, (2015) Barley flour addition decreases the oil uptake of wheat chips during frying. Qual Assur Saf Crop Foods 7(5): 621-628.

26. Ajila CM, Leelavathi K, Rao, UP (2007) Improvement of dietary fibre content andantioxidant properties in soft dough biscuits with the incorporation of mango peel powder. J Cereal Sci 48(2): 319-326.
27. Larrea MA, Chang YK, Martinez-Bustos F (2005) Some functional properties of extruded orange pulp and its effect on the quality of cookies. LWT-Food Sci Technol 38: 213-220.

28. Meyer KA, Kushi LH, Jacobs DR, Slavin J, Sellers TA, et al. (2000) Carbohydrates, dietary fibre, and incident type 2 diabetes in older women. Am J ClinNutr 71(4): 921-930.

29. Liu S, Manson JE, Stampfer MJ, Hu FB, Giovannucci E, et al. (2000) A prospective study of wholegrain intake and risk of type 2 diabetes mellitus in US women. Am J Public Health 90(9): 1409-1415.

30. McKeown NM, Meigs JB, Liu S, Wilson PW, Jacques PF (2002) Wholegrain intake is favorably associated with metabolic risk factors for type 2 diabetes and cardiovascular disease in the Framingham Offspring Study. Am J ClinNutr 76(2): 390-398.

31. Devalaraja S, Jain S, Yadav H (2011) Exotic Fruits as Therapeutic Complements for Diabetes, Obesity and Metabolic Syndrome. Food Res Int 44(7): 1856-1865.

32. Qadri OS, Srivastava AK (2017) Microwave-Assisted Foam Mat Drying of Guava Pulp: Drying Kinetics and Effect on Quality Attributes. J Food Process Eng 40(1):1-8.

33. Younis K, Siddiqui S, Jahan K, Dar MS (2014) Production of wine from over ripe guava (Psidiumguajava L Cv. Safada) and ber (Ziziphusmauritiana L Cv. Umran) fruits using Saccharomyces crevices Var. HAU 1. J Environ SciToxicol Food Technol 8(1): 2319-2402.

34. Ramdath D, Renwick S, Duncan AM (2016) The Role of Pulses in the Dietary Management of Diabetes. Can J Diabetes 40(4): 355-363.

\section{Your next submission with Juniper Publishers will reach you the below assets}

- Quality Editorial service

- Swift Peer Review

- Reprints availability

- E-prints Service

- Manuscript Podcast for convenient understanding

- Global attainment for your research

- Manuscript accessibility in different formats

( Pdf, E-pub, Full Text, Audio)

- Unceasing customer service

Track the below URL for one-step submission https://juniperpublishers.com/online-submission.php 